\title{
School Leadership Role in a Conflict and Post-Conflict Environment School Reconstruction as a Professional Learning Community
}

\author{
David Nkengbeza \\ University of Namibia, Katima Mulilo Campus, Namibia \\ Email: dnkengbeza@unam.na
}

Received 19 May 2016; accepted 19 August 2016; published 22 August 2016

Copyright (C) 2016 by author and Scientific Research Publishing Inc.

This work is licensed under the Creative Commons Attribution International License (CC BY). http://creativecommons.org/licenses/by/4.0/

(c) (i) Open Access

\begin{abstract}
Understanding the role school leadership plays in rebuilding schools as professional learning communities is a crucial step forward in tackling the numerous challenges of conflict and post-conflict school reconstruction. The purpose of this article is to find out the role school leadership plays in a conflict and post-conflict environment school reconstruction as a professional learning community. Qualitative research method was used and the data were collected using interviews. The major findings included a shared supportive leadership that worked collaboratively with other stakeholders to overcome its challenges, provided the needed supportive conditions and reforms and overcame its psychological challenges. This article challenges schools and all those involved in education in conflict and post-conflict societies to rethink their school improvement strategies.
\end{abstract}

\section{Keywords}

School Leadership, Conflict, Post-Conflict Environment, School Reconstruction, Teacher Leadership, Student Leadership, Professional Learning Communities, Community of Learners, School Effectiveness, School Improvement

\section{Introduction}

Education is crucial in rebuilding shattered societies in both conflict and post-conflict environments. Schools in conflict and post-conflict environments face many challenges including trauma, loss of life, lack of qualified teachers, hate, destruction of schools and other infrastructures, lack of finance, absence of state running systems, increase in corruption and poor management, youths with no profession or skills, high unemployment rate, a 
dangerous environment not conducive for learning, available guns in the wrong hands, and a society that is impregnated by fear and loss of hope [1] [2].

Professional learning communities (PLCs) bring general satisfaction, higher moral and low dropout and absenteeism for both students and teachers. Also important is the view that PLCs build lasting school system level improvement for the benefit of the whole school. With PLCs there is a great improvement in teachers' network, professional collaboration and expanded professional role among all the stakeholders, and even more important is the fact that PLCs improve teachers' efficacy and enhance teachers' effectiveness for the benefit of the students [3].

The school leadership is at the centre of every school improvement. For the school leadership to be successful it must involve all the stakeholders in its improvement plan, lead the design of the plan, monitor its implementation, enhance policies and as Leith wood and Riehl [4] have put it: effective school leadership develops their schools guided by a vision that symbolises and embodies their collective thinking about teaching and learning. Very little is known about the role of school leadership in rebuilding schools as PLCs in conflict and post-conflict societies. This article is taken from a major project that I did in 2014 and it seeks to cover this gap.

\section{Problem Statement and Research Question}

As shown in Figure 1.

School leadership: The principal is at the centre of school leadership but he/she is not alone. In PLCs, power is shared or distributed among the other stakeholders in a school. These members, depending on the context, include the Parent Teacher Association (PTA), school governing board, vice principal, student leaders, head of department and other team leaders. All these leaders are responsible for the implementation of school improvement and the change process in the school. Professional learning community: While Harris [3] defines professional learning community as a "group of connected and engaged professionals who are responsible for driving change and improvement within, between and across schools that will directly benefit learners", Nkengbeza [5] believes that a professional learning community is an inclusive education institution that shares responsibility and decision-making, and continuously and collectively questions the status quo, seeks for better school improvement strategies or tools and is guided by shared values and vision. Conflict and post-conflict environment: While a conflict environment is the actual environment where conflict takes place, a post-conflict environment is the immediate period that proceeds the conflict period. This era continues until the age of normalcy is restored. It should be noted that there is no clear cut between these two periods [5].

Very little is known about the role of school leadership in building professional learning communities in conflict and post-conflict environments. Goddard [6] has only written on "The role of the school leaders in establishing democratic principles in post-conflict societies" using the case of Kosovo arguing that education is the vehicle of change in trauma healing in post-conflict communities. According to him, education should be the agent of transformation and also that the school leadership should be given the role to build a collegial culture of trust. In his article, he recommended that PLCs should be established in schools in Kosovo to handle the numerous challenges in education in post-conflict Kosovo. This article aims to further this discussion on the role of school leadership in rebuilding one school in conflict and post-conflict Liberia.

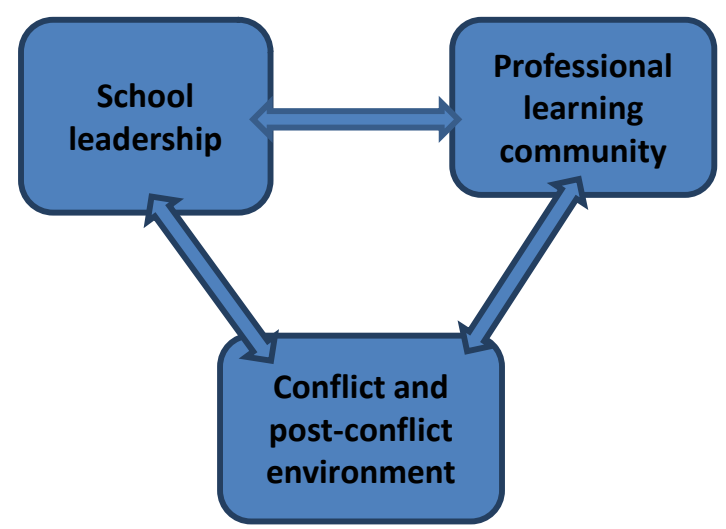

Figure 1. Problem statement of the study. 
The research question: The main research question is: What is the role of school leadership in building a school as a professional learning community in a conflict and post-conflict environment?

\section{The Framework for the Study}

Due to the complex nature of school organizations today, the principal alone can no longer perform the leadership role. In conflict and post-conflict societies, rebuilding schools is even more daunting because of the many challenges it faces. Therefore, as a consequence, the principal and the school leadership team ought to practice distributed leadership, share responsibilities and support all the staff. The school leadership teams should work collectively towards school improvement and they should be guided by shared values and vision. The school leadership needs to provide supportive conditions for the establishment and sustaining of PLCs and also establishes an environment where peers share their personal practice [7].

\subsection{The Principal Practices Distributed Leadership, Shares Responsibility and Supports All Its Staff Members}

Distributed leadership is built on the notion that power is shared across the whole school or organisation [3]. As the search on school improvement tools continues and coupled with the tremendous advantages brought along with it when a school develops as a professional learning community, distributed leadership becomes central in the school development. The old system that looked at the principal as all powerful has been shifted as schools have become increasingly complex organisations. The terms shared, distributed and collaborative leadership have become very familiar in many schools that have developed the culture of learning organization. School leadership today is no longer the property of an individual, and it is an interaction across the school and among all the stakeholders [8].

\subsection{Work Collectively for the School Improvement}

Collaborative working in teams is also at the centre of PLCs development. Hord [7] defines collaborative leadership as a situation where "power, authority, and decision making are distributed across the community". Collaboration has been facilitated in the twenty-first century with the advent of different technologies. Collaborative learning today has expanded from within the school teams to a network with other schools and teams, both national and international. This has led to the exchange of good practices, depending on the context of the school. Collaborative leadership in PLCs, as explained by Webb, Vulliamy, Sarja, Hamalainen and Poikonen [9], helps in promoting teacher motivation and welfare-key factors that help inspire students. Collaborative working by all the stakeholders in the school helps with developing a culture of trust which is crucial for the success of PLCs.

\subsection{Guided by Shared Values and Vision}

If we define values as the binding norms of an organization, we would also agree with Stoll, Bolam, McMahon, Wallace, and Thomas [10] that a good shared vision in PLCs gives a sense of purpose and direction. With such a vision in place teachers are not isolated, they do not only count on each other for support, they believe in collective ethical decision-making [10]. Claus on, Aquino and Wide man [11] have explained that these norms should be defined by group collective views. Organizational values and vision help in developing interpersonal skills, such as trust, communication and collaboration and equally develop the content knowledge in the case of schools [12]. All the stakeholders should be involved in the development of a school vision and these stakeholders include teachers, administrators, school board members, parents and even students. Hord [7] believes that PLCs should be guided by shared beliefs, values and a vision of what the school should be like. With shared values and vision, all the stakeholders in the school share their thinking and the best ideas are taken [11].

\subsection{Provide Supportive Conditions}

Available supportive conditions are vital for sustaining PLCs in schools in conflict and post-conflict environments and also in ordinary environments. Supportive conditions are either relational or structural. As agreed by Hord [7] and Nkengbeza [5], while relational conditions include respect, caring and the building of trust among the stake holders, structural conditions include time and place to meet and plan and the resources needed to establish and sustain a PLC. Effective school leadership offers intellectual stimulation to all its stakeholders. They 
encourage reflection and challenge the staff to rethink how to improve student learning. The school leadership also provides the needed support to all the staff and is a role model and consistent with the school goals and values. [4]

\subsection{Provide an Environment Where Peers Share Their Personal Practice}

PLCs provide an environment where peers share their personal practice, gain feedback and this leads to the overall improvement of the individuals and the school [5] [7]. PLCs have been credited for creating an environment where everyone shares his/her practices and supports each other [13].

\section{Research Methodology}

\subsection{Qualitative Research Method}

A qualitative research method was used in this paper. Hanson, Balmer and Giardino [14] have explained that "qualitative researchers employ rigorous methods of sampling, data collection, analysis, and interpretation with in a framework of scientific inquiry". According to Hanson [14] and colleagues, qualitative researchers use different sets of assumptions to interpret issues through different lenses, within different contexts. The different strategies in qualitative research according to Creswell [15] include narrative, phenomenology, case study, ethnography and Grounded theory. In this study a qualitative research method (a case study) was used because the researcher wanted to understand the role of school leadership in building a school as a professional learning community in a conflict and post-conflict environment. An interaction with those who took part in the change process was the best way to understand what they went through (see data collection method).

\subsection{School Selection Method}

The case school was selected using expert testimony. An expert in education was asked to select a school using certain criteria for good schools (developed by the University of California), which are a reflection of professional learning communities. These criteria, among others, included professional administrators and teachers who were knowledgeable with the curriculum, a supportive leadership led by the school principal, a good curriculum that helped students to achieve their potentials, and a safe and conducive environment in which students could learn. With these criteria, a case school that succeeded to implement change and turnaround in Liberia (a country that went through 14 years of civil wars) was selected. I cannot say how many of these schools were available in the country at the time, but it should be noted that in many post-conflict environments, turn-around successful schools are difficult to find. The school had about 500 students and pupils (Grades 1 - 12). Unlike the immediate part of the post-conflict era, students in grade 12 were not more than 18 years old.

\subsection{Data Collection Methods}

This article is part of a major project I did in 2014. The data for the major project was collected using three main methods: interviews, document review and observations. For this article the major data collection method was through interviews (focus groups and individual face to face). The interviews were conducted in three phases. In faze one there were interviews at the case school (a total of 14 interviews including the principal, priest, viceprincipal, administrative staff and teachers). In phases two interviews were conducted about the student leadership and the student palaver management team (SPMT) at the case school (both were interviewed in focus groups separately) and phases three was about the PTA (the PTA chairperson and secretary were also interviewed separately). A voice recorder was used to record interviewees' responses and individual and focus group interviews were used. It should be noted that there is only one principal and a vice principal and both were interviewed at different levels/phases to collect different data.

There are a series of documents that I have reviewed and they have helped in understanding the role of school leadership in rebuilding schools in conflict and post-conflict situations like: the student handbook, the student palaver management handbook for interveners and palaver managers - 2nd edition, the parent teacher association development and operational manual and The national curriculum revised June 2011: Grades 1 - 12. I also used observation in a limited way to increase reliability as it helped to provide a better view of the context and phenomenon that I was studying [16]. 


\subsection{Data Analysis}

The analysis for this article was done using the conceptual framework and thematic analysis. The conceptual framework for building PLCs were investigated in the case school and also used in the analysis of the data and the extent to which these components were present in the school are explained. Content analysis was also used. Major themes were also generated from the content of the study, mainly from the data collection methods (mainly interviews and a bit of document review and observation). Marshall and Ross man [17] have rightly explained that data analysis deals with generating categories and themes and that "is the most difficult, complex, ambiguous, creative, and fun" experience [5] [17].

\section{Findings}

The major findings for the role of school leadership are as follows: The school leadership shares responsibilities and supports its staff, works collectively for school improvement, tackled the challenges faced by the school, provides supportive conditions, provides an environment where peers share their personal practice and the school leadership are guided by shared values and vision. The school leadership brought reforms that were sustained by the establishment of a PLC in their school.

\subsection{The School Leadership Shares Responsibility and Supports Each Other}

At the centre of the school leadership is the principal who was a student of the case school, and now teaches there. During the civil wars he escaped to Ghana, studied and returned after the war and was appointed as the new principal to lead the school. His leadership is highly distributed and/or shared. At the top is the local school board that consists of nine members, followed by the principal and vice-principal. While the junior church warden is the chairperson of the local school board, the principal is the secretary. Other board members include the PTA chairman and secretary, a representative from the Alumni Association, a businesswoman from the community, a lawyer, a medical practitioner and the priest. The LSB develops funding strategies and advices the principal. This board meets twice a year and also on request of the principal, when the need for extra meetings arises.

Under the vice-principal, for administration, are the registrar, cashier and the secretary. The principal is responsible for the functioning of the whole, and he gives support to all the staff members. Directly under the vice-principal, there are three departments: the academic, disciplinary, and sports department-headed by a department head and each teacher in the school belongs to one of these departments. At the bottom of this leadership chain are the student leaders and student palaver management team.

\subsection{The School Leadership Works Collectively for School Improvement}

As explained earlier teachers are placed under three different departments: an academic, discipline and sports department. The teachers in the academic department work as a team and assist the teachers when they experience problems with academic work. They address all academic problems like students' performances in different subjects, introduction and dropping of subjects depending on the strategic evaluation of the society's future needs. The disciplinary committee on the other hand is responsible for handling students' problems. In the postperiod immediately after the war, the school counsellor worked for both students and teachers and sometimes with the principal (in a situation where he was part of the solution).

There is a general agreement that there has been a marked improvement in the sports department and because of that many students have been attracted to this school. Players are well taken care of during sporting activities like inter-college games. Various scholarships, ranging from whole tuition free to partial tuition free have attracted many students and this explains why the school has become very popular. Teachers are very cooperative and support each other- "students are never left alone in their classrooms".

Professional development is taken seriously in the school. There are two workshops every year and trainers come from the Teacher's College and the Ministry of Education. While the student leadership provides its skills in leading students, be it in sports, social activities or student-student dialogue/counselling, the SPM concentrates on solving or settling student disputes. All the various stakeholders in the school work together, searching for better ways of teaching and solving problems collaboratively for the general progress of all the students and teachers in the school. 


\subsection{How the School Leadership Tackled Its Challenges}

Insecurity and hate: Countering this challenge was done through collaboration with the Christian Health Association of Liberia (CHAL). The "CHAL came up with an idea to establish the Student Palaver Management Teams (SPMT) in various schools to take care of problems between students, thus giving teachers the opportunity to concentrate more on teaching" [5]. The success of the student palaver management in schools is due to the collaboration between the Christian Health Association of Liberia and The United Nations International Children Emergency Funds (UNICEF). The establishment of SPMT in the case school helped to solve problems between students. The church also provides an environment where both teachers and students open up on the problems they are going through. It was through this process that both student and teachers came to understand that they had all suffered during the war and that there was no need to continue to hate each other.

Drug use and student misbehaviour: Drug use was another major problem brought by the Liberian civil wars. It is even said that "students were not able to buy study materials" but spent much money on buying drugs. Some of the students became government employees, like policemen, after the war and it is said that some of them were not very cooperative. After the war, people of various backgrounds returned to school (including the rich and poor, and those with questionable behaviour), and some of them did not respect the teachers. Cooperation with the police and the society succeeded to eradicate the source of the drugs. Students' counselling, discipline and the help from other stakeholders greatly reduced students' misbehaviour.

Lack of funding and qualified teachers: A common phenomenon in the conflict and post-conflict societies is the lack of funding. In the case school funding was not available immediately after the war, and thus, teachers were poorly paid. Qualified teachers were not available, especially during the conflict and the immediate part of the post-conflict period. At a later stage of the post-conflict period, teachers were given the opportunity to be trained. The school succeeded in bringing in more qualified and good teachers. With the coming of qualified and dedicated teachers, the school became more outstanding, especially in its community and later-on nationally.

Bringing students and teachers back to school, low salaries and crimes: Bringing students and teachers back into classrooms was a school leadership problem after the war. Trauma is a deeply distressing or disturbing experience, in the case school both students and teachers had been traumatized by the war. Immediately after the war, students and teachers distrusted each other, and this further added to students' disciplinary difficulties. The change of principal brought high hopes for the school as he was loved by many in his community and this led to many students' return. Another major reason that brought students back was because the new principal was quite respectful. Teachers decided to return to school because the new principal promised to look into their problems. The problem of low salary was solved when the new principal came. There was a general increase in salaries and teachers were paid for extra classes to increase their salaries. Disciplinary problems were handled through the cooperation with other stakeholders like the Parent Teacher Association, the school disciplinary committee, the student leadership and with the help of the student Rules and Regulation Handbook.

\subsection{The School Leadership Is Guided by Shared Values and Vision}

"The school values/symbols included the school ode, the scorpion, the school flag, the church and prayers" [5]. While the scorpion symbolizes "hope, perseverance and strength", the school flag reminds students of the symbol of the school name, ink, books and a bible. These symbols are on the school flag. The school's name reminds all the stakeholders (students, staff, parents, community and other) what the school stands for. The ink stands for the writing materials. The book symbolises the knowledge which students are to receive and finally the bible is a symbol of guidance representing Christian principles. There are also symbols of the church and prayers. The school's vision is "strive to achieve" — created in 1959 when the school was established.

\subsection{The School Leadership Provides Supportive Conditions}

The school leadership provides supportive conditions for general school improvement to take place. The school is divided into three departments (sports, academic and discipline) with various functions. The free food programme after the wars provided food for all children, but after the school improved, the food was distributed only among needy children in community schools. The construction of the school fence helps to control and regulate entry to the school campus, when students enter the school and when they leave. It is said that the construction of the school fence brought a marked improvement in student discipline. Together with available sup- 
portive learning and staff development, there are rewards for students' and teachers' high achievement. The student leaders and the student palaver management team provide disciplinary and other support, and time and space are provided for staff meetings to take place.

\subsection{The School Leadership Provides an Environment Where Peers Share Their Personal Practice}

Interviewees explained that peers share their personal practices. An example was the introduction of the "student pass system" by a teacher who was looking for ways to curb students standing out of the class during lectures. Apparently students used to stand outside of their classrooms, especially in the morning, until the student "pass" system was introduced. When the "pass" was first introduced, the teacher was glad with its effectiveness. He then shared it with his colleagues and it was later implemented in the whole school.

\section{Discussions and Conclusions}

The school leadership accepts shared responsibilities and leads the learning process. They are change leaders who practice distributed leadership, teachers' leadership and student leadership. The leadership does not only provide the needed support for change to take place, and they bring along school reforms and collaborate with other stakeholders. They are guided by a compelling vision and values.

\subsection{The School Leaderships Are Change Leaders and They Practice Distributed Leadership Including Teachers' Leadership and Students' Leadership}

The principal is at the centre of school leadership. He is committed to the use of distributed leadership across the school. While the school local board helps the principal as a consultative body before major changes are implemented in the school, the PTA collaborates with the school administration to improve student development. There are also other administrative staff members like the registrar, secretary and the cashier who play key roles in the school's success.

The school leadership practices and promotes teachers' leadership in the school. Teachers do not only teach, but they are also placed under three different departments (academic, disciplinary and sports) according to their other expertise. The sports committee on the other hand is responsible for all sporting and social activities in the school. Scholarships are given to students who perform well in sports. These findings are in accordance with those of other researchers like Leith wood and Riehl [4] that leadership's effect on school success is both direct and indirect. School leadership works through team work and these leaders establish effective conditions that make the change system effective.

There are student leaders who provide much needed help in coordinating the different school activities. While the class prefects make sure that their respective classrooms are in order for learning to take place, the school prefects are in charge of school activities. The student palaver management team helps the settlement of conflict between students. This group is made up of interveners and managers. While the interveners have been trained to search for conflicts between students and bring those involved to the managers, the managers have been trained and are actually responsible for the settlement of the conflicts. This group is accredited for reducing the conflicts which have existed between students after the war.

\subsection{The Leadership Provides the Needed Support for Change to Take Place}

There is a time scheduled for general staff meetings and for other committee meetings, where issues are debated on and resolved. There are funding for different projects, and teachers' expertise is promoted through professional development to support and cement the change in their school. The school leadership ensures ample opportunities for staff development. The teachers have two major workshops for professional development each year and the trainers are usually from the Ministry of Education and the Teachers' College-including a teacher from their school. Members in each of the three department set expectations that are in alignment with the school goals. The strength of these leaders is in their collective learning. They rely on each department to work effectively and solve problems. The school leadership monitors the system for the implementation of reforms. The school leaders act as mentors and coaches to support the development of all the staff. 


\subsection{The School Leadership Brought School Reforms and Collaborated with Other Stakeholders}

Credit for the school reforms was given to their principal who had escaped to Ghana during the war and returned during the post-conflict period. His role was instrumental in bringing lasting reforms to the school. The school fence helped considerably in improving the school. With the new fence, students could no longer leave the school grounds as they wish. Parents were glad because they knew their children were safe on the school grounds and they knew when to expect them to get home. The accelerated learning program also helped to solve the problem of older students who were in the same class with the younger ones. The night school was introduced to older students and this lead to fast promotion for the older children.

It is said that the school uniform helped in bringing students back to school. The school uniform not only instils discipline in the students, it also brings a sense of self-worth and equality among them. The cost of clothing is with no doubt drastically reduced and it also reduces competition and social conflict among the students. The uniform promotes students' loyalty as they are easily distinguished wherever they go and this improves their morale. It is said that students from the case school take up the responsibility of counselling other students from different schools in the municipality on the effects of the civil war. They also improve student behaviour beyond their school, and this has brought them credit. The teachers' salaries were increased and more professional teachers were brought to the school. Another important reform was the establishment of a support system where both students and teachers are given the opportunity to overcome their psychological challenges. The feeding program, sponsored by the United Nations, has brought many students back to school. Outsiders were contracted to sell food to students on the campus, when food distribution ended.

The school leadership collaborates with other stakeholders like the international community. The school fence was constructed thanks to the funding from ECOWAS. The United Nations provided funding to the school immediately after the war. Everyone was poor and students had no money to pay fees. The United Nations office in Monrovia contributed a certain amount to the school for each student who was enrolled in the school. The United Nations Office for Project Services (UNOPS) was named as one of the organisations that assisted in roofing the school after the war.

\subsection{They Are Guided by a Compelling Vision and Values}

Their school vision (strive to achieve) was developed in 1959 when the school was established and it is still very relevant to them. Their values/symbols include the bible and the scorpion. While the bile symbolises their guided principles, the scorpion symbolises their strength to survive in all types of environments. They went through 14 years of civil wars where the school was almost completely destroyed. They developed and strengthened their school performance foundation, including the vision and values/beliefs which were aligned with their school goals. These school goals are focused on student achievement. The school leadership creates a peaceful and inclusive environment where every student learns. It is this peaceful and conducive environment that enables teachers to share their good practices for the benefit of the entire school. Students from various religious denominations are enrolled in the school. Leith wood and Riehl [4] have concluded that "effective school leadership help their schools to develop visions that embody the best thinking about teaching and learning".

Background: Education in conflict and post-conflict environments has continued to suffer because it is not a major priority for most of the major actors in these eras. Smith [18] has advocated the view that in post-conflict societies more focus should be given to the youths in addressing their needs and that education should address the past. In the case of civil wars, the new leadership must be courageous to accept and address what they have done wrong and end the blame game. Education is a tool which should be used to address war conflicts in all its forms. Nkengbeza [5] has advocated the introduction of peace education in schools in ordinary societies and in conflict and post-conflict societies to prevent the emergence of conflict. "Education does not cause wars, nor end them; every education system has the potential either to exacerbate or to mitigate the conditions that contribute to violent conflict" [1].

Research question: This paper has answered the main research question (What is the role of school leadership in building a school as a professional learning community in a conflict and post-conflict environment?). The school reforms are encouraging and the school leadership practiced shares supportive leadership, works collectively for school improvement, and tackles the challenges faced by the school, provides supportive conditions, provides the needed reforms and also provides a conducive environment where peers share their personal prac- 
tice. This paper has provided schools, educational leaders and other nation builders in conflict and post-conflict societies an example on how schools can be turned around in hostile environments. With the current pressure on various educational actors at all levels to perform (students, teachers, principals and educational directors as in South Africa), looking at the role of school leadership in rebuilding schools in conflict and post-conflict environments offers a new perspective for school improvement in hostile societies [4].

Practical implications for schools and nation builders: This paper has provided an insight on the role of school leadership in rebuilding schools in conflict and post-conflict environments. I believe that schools in fragile environments will learn from this case and educational leaders and nation builders will start using the lenses of PLCs in reconstructing schools and education in general. PLCs should be implemented in conflict and postconflict environments because they provide a "system-wide change, system collaboration and networking, ... non-negotiable focus on pedagogical improvement and improving learner outcomes ... [and] the model uses action enquiry approaches as a driver for change" [3]. The school leadership in conflict and post-conflict environments therefore should be visionaries, collaborators, leaders/managers, mediators, supporters, teachers and researchers.

Limitation and suggestion for further studies: There are many actors in conflict and post-conflict school reconstruction. The school leadership is only one component and the others include the international community and government (education) policies. It should also be noted that the major project that this data is part of was not about the role of school leadership. It was only after the data collection that the role of the school leadership emerged and as such some of the findings have not been described concisely and in-depth. It will be a good idea to explore the role of these other stakeholders in rebuilding schools in conflict and post-conflict societies.

\section{Acknowledgements}

This article was funded by North-West University, Potchefstroom campus during my tenure there as a Research Fellow.

\section{References}

[1] Buckland, P. (2006) Post-Conflict Education: Time for a Reality Check. Forced Migration Review, 7-8. http://www.fmreview.org/sites/fmr/files/FMRdownloads/en/FMRpdfs/EducationSupplement/full.pdf

[2] Hunter, J. (2013) Professional Learning Communities. p. 6.

[3] Harris, A.J.S. (2008) Distributed Leadership through the Looking Glass. British Educational Leadership, Management and Administration Society, 22, 31-34.

[4] Leith Wood, K.A. and Riehl, C. (2003) What We Know about Successful School Leadership. National College for School Leadership, Nottingham.

[5] Nkengbeza, D. (2014) Building a Professional Learning Community in a Conflict and Post-Conflict Environment: A Case-Study of a High School in Liberia. University of Jyvaskyla, Jyvaskyla.

[6] Tim Goddard, J. (2004) The Role of School Leaders in Establishing Democratic Principles in a Post-Conflict Society. Journal of Educational Administration, 42, 685-696. http://dx.doi.org/10.1108/09578230410563674

[7] Hord, S.M. (2009) Professional Learning Communities: Educators Work Together towards a Shared Purpose. Journal of Staff Development, 30, 40-43.

[8] Mayrowetz, D. (2008) Making Sense of Distributed Leadership: Exploring the Multiple Usages of the Concept in the Field. Educational Administration Quarterly, 44, 424-435. http://dx.doi.org/10.1177/0013161X07309480

[9] Webb, R., Vulliamy, G., Sarja, A., Hämäläinen, S. and Poikonen, P.L. (2009) Professional Learning Communities and Teacher Well-Being? A Comparative Analysis of Primary Schools in England and Finland. Oxford Review of Education, 35, 405-422. http://dx.doi.org/10.1080/03054980902935008

[10] Stoll, L., Bolam, R., Mcmahon, A., Wallace, M. and Thomas, S. (2006) Professional Learning Communities: A Review of the Literature. Journal of Educational Change, 7, 221-258. http://dx.doi.org/10.1007/s10833-006-0001-8

[11] Clausen, K.W., Aquino, A.-M. and Wideman, R. (2009) Bridging the Real and Ideal: A Comparison between Learning Community Characteristics and a School-Based Case Study. Teaching and Teacher Education, 25, 444-452. http://dx.doi.org/10.1016/j.tate.2008.09.010

[12] Huffman, J. (2003) The Role of Shared Values and Vision in Creating Professional Learning Communities. NASSP Bulletin, 87, 21-34. http://dx.doi.org/10.1177/019263650308763703 
[13] Morrow, J.R. (2010) Teachers' Perceptions of Professional Learning Communities as Opportunities for Promoting Professional Growth. Doctoral Dissertation, Appalachian State University, Boone.

[14] Hanson, J.L., Balmer, D.F. and Giardino, A.P. (2011) Qualitative Research Methods for Medical Educators. Academic Pediatrics, 11, 375-386.

[15] Creswell, J.W. (2013) Research Design: Qualitative, Quantitative, and Mixed Methods Approaches. Sage Publications, London, 26.

[16] Kawulich, B.B. (2005) Participant Observation as a Data Collection Method. Qualitative Social Research, 6, 43.

[17] Marshall, C. and Rossman, G.B. (1999) Designing Qualitative Research. 3rd Edition, International Educational and Professional Publisher, California, 35.

[18] Smith, A. (2009) The Influence of Education on Conflict and Peace Building, Background Paper Prepared for the Education for All Global Monitoring Report 2011 the Hidden Crisis: Armed Conflict and Education. UNESCO, Paris, 19.

\section{Submit or recommend next manuscript to SCIRP and we will provide best service for you:}

Accepting pre-submission inquiries through Email, Facebook, LinkedIn, Twitter, etc.

A wide selection of journals (inclusive of 9 subjects, more than 200 journals)

Providing 24-hour high-quality service

User-friendly online submission system

Fair and swift peer-review system

Efficient typesetting and proofreading procedure

Display of the result of downloads and visits, as well as the number of cited articles

Maximum dissemination of your research work

Submit your manuscript at: http://papersubmission.scirp.org/ 